\title{
Public Enthusiasm for Integrated Islamic Schools
}

\author{
Imron Rasyadi \\ Universitas Islam Negeri (UIN) Sultan Thaha Saifuddin Jambi, Jl. Arif Rahman Hakim \\ No.111, Simpang IV Sipin, Telanaipura, Jambi, Indonesia \\ imrasyadi@gmail.com
}

\begin{abstract}
This article aims to express the enthusiasm of the community (parents) to entrust their children to study at the Integrated Islamic School. Since the outbreak of the Integrated Islamic School, it has emerged amid the community that not only the existence of the school is in the province but has penetrated districts and cities in Indonesia. The author's observation is that the Integrated Islamic School is the main attraction for parents to entrust their children. Even in the last five years, this school has continued to increase the number of students who register. On this basis, the author is very interested in examining what factors attract parents to send their children to this school more deeply. This research is qualitative research that seeks to capture and translate the phenomena and facts related to the Integrated Islamic Elementary School (SDIT) Permata Hati Merangin Jambi with a descriptive-analytical method, which describes what findings were obtained based on interviews, observations and documentation, then analyzed using inductive and deductive theories so that the object of the research is well represented. The results found are the enthusiastic factors of the community (parents) entrusting their children to the Integrated Islamic School, namely (1) the integration of the Religious Education curriculum with general education; it is implemented and not just a mere slogan; (2) Integrated Islamic School Implementing a full day school learning system, because this model system has many benefits, especially respect for time, and (3) Parents are personally involved actively in guiding children to learn.
\end{abstract}

Artikel ini bertujuan mengungkapkan antusias masyarakat (orang tua) untuk menitipkan anak-anak menimba ilmu di Sekolah Islam Terpadu. Semenjak mewabahnya Sekolah Islam Terpadu muncul ditengah-tengah masyarakat yang tidak hanya keberadaan sekolah tersebut di Provinsi saja tapi sudah merambah pada Kabupaten dan Kota di Indonesia. Pengamatan penulis bahwa Sekolah Islam Terpadu menjadi daya tarik tersendiri bagi orang tua untuk menitipkan putra-putrinya bahkan pada lima tahun terakhir sekolah ini terus meningkat jumlah siswa-siswi yang mendaftar. Atas dasar inilah penulis sangat tertarik untuk mengkaji lebih dalam faktor apa-apa saja yang menjadi daya tarik orang tua menitipkan anak-anak mereka di sekolah ini. Penelitian ini adalah penelitian kualitatif yaitu berupaya menangkap dan menerjemahkan fenomena dan fakta-fakta yang berkaitan dengan Sekolah Dasar Islam Terpadu (SDIT) Permata Hati Merangin Jambi dengan metode deskriptif-analitis, yaitu memaparkan temuan apa yang diperoleh baik berdasarkan wawancara, observasi maupun dokumentasi, selanjutnya 
dianalisa menggunakan teori induktif dan deduktif sehingga tergambar objek penelitian tersebut dengan baik. Hasil yang ditemukan adalah faktorfaktor antusias masyarakat (orang tua) menitipkan anak mereka di Sekolah Islam Terpadu adalah (1) integrasinya kurikulum Pendidikan Agama dengan pendidikan umum; hal ini benar-benar dilaksanakan dan tidak hanya sebagai slogan belaka; (2) Sekolah Islam Terpadu Menerapkan system pembelajaran Full day school, karena system model ini sangat banyak manfaatnya terutama penghargaan terhadap waktu, dan (3) Orang tua secara person dilibatkan secara aktif dalam membimbing anak belajar.

Keywords: Community Enthusiasm, Education, Integrated Islamic School.

Received: October 6, 2021; Revised: November 2, 2021; Accepted: December 5, 2021

\section{INTRODUCTION}

Islamic boarding schools have become integral parts of Indonesian education (Ikhwan, 2017). These schools are managed by Islamic institutions, the so-called Pondok Pesantrens, as indigenous education, phenomenal. Today most of them organize both religious and formal instructions such as Schools. They became the central attention of families and communities that demanded moral and spiritual education (Ikhwan, Biantoro, \& Rohmad, 2019). At Junior High Schools, they provided foreign language instructions, both Arabic and English. English turned out to become essential to learn both in class and outside classrooms for speaking developing skills. It has been interesting to study as English is known at the same time as Arabic.

Participants' participative observation in East Java, Indonesia, from June to July 2019 showed that English was considered the flagship lesson and unique program as Arabic was. The English program was observed because there are no activity subscriptions besides the researcher's management and English education background. Results of an interview with these two schools leaders, the so-called Kyai, Principals, Teachers, and Students confirmed that English and Arabic were prioritized foreign language subjects to learn formally and informally. Even though students were enthusiastic, teachers still found it challenging to implement the 2013 English curriculum using the scientific approach. They needed on going professional development. It is essential that teachers are professional (Mutohar, 2006), but not all teachers can efficiently work professionally (Imron, 2011). Thus, professional assistance shall be given (Zepeda, 2007). Supervision can be the way to support on going professional development (Suhardan, 2010). A suitable model of English Instructional Supervision was needed. In his research on the participative supervision model in Pondok Pesantren, he found out that Kyai, Principals, Vice Principals, and Teachers focused on teachers' disciplines and behaviour (Supriyono, 2018). There were still problems in teachers professional supports. The practice of collaborative c munication showed positive results of teachers' professional improvement. Supervision was expected to be a problem-solving alternation.

This research proposed establishing clinical and collaborative Supervision for scientific-based English instruction of Islamic Boarding Junior Middle Schools. The research question was formulated about how the established clinical joint Supervision for Scientific based English Instruction of Islamic boarding school at the junior high 
school level was formed. This research was expected to provide continuous professional development for English teachers at Islamic Boarding Middle Schools.

\section{LITERATURE REVIEW}

Anxiety about the condition of education in Indonesia, which is getting heavier, is realized by educators in Indonesia. Meanwhile, the results of schooling so far have not achieved the results expected by all parties. The high level of violence and society's shifting values and ethics are considered an indicator that there are still many shortcomings in the world of education (Simatupang \& Abduh, 2020). Then it becomes a joint conclusion that education in this country only emphasizes students' cognitive abilities and ignores ethical education and religious education (Aryati, 2016).

From here, at least an idea emerged to realize a better colour of Islamic education. It integrates Islamic knowledge combined with general science, which is presented professionally. It always follows the times with the hope of the birth of an Islamic generation capable and reliable in available science, which has the foundation and attitude by the teachings of Islam (Siregar, Zahra, \& Bujuri, 2020). One concept is popularly known as the Integrated Islamic School.

Integrated Islamic Education The term "integrated" in the education system is intended to reinforce (littaukid) Islam itself. The point is that Islam is complete, comprehensive, integral, not partial, meaning that education is not only oriented to one aspect. The existing education system must combine elements of forming a superior education system. Islam views education as something identical and inseparable from the origin of human creation (fitrah insaniyah). Man himself is the body, spirit, intellect. Thus, education in the view of Islam includes three aspects that cannot be separated, which include physical education (tarbiyah jasadiyah), spiritual education (tarbiyah ruhiyah), and academic education (tarbiyah 'aqliyah)(Sabda, 2006); (Ikhwan, 2018).

Nowadays, integrated Islamic schools are increasingly being taken into account, and this can be seen from the increasing number of schools that use the "integrated" label. As a tit for tat, the public's interest in this school is even more significant, even though the cost is relatively high for a similar school. Along with the reform of the integrated Islamic education model, the Merangin Jambi Regency is also not left behind because the Integrated Islamic Elementary School (SDIT) has been established, which provides an alternative solution to the concerns of guardians of students regarding the current output of education that has not been able to fulfil the nature of the educational goals set out in the previous year. As the Merangin Jambi community's interest in entrusting their children to this SDIT increases every academic year, it is constantly growing (Suyatno, 2015); (SDIT Permata Hati Merangin Jambi, 2021).

There have been studies related to Integrated Islamic Schools that have reviewed it, such as the results of research by Yusni Ramdhani et al., which discusses in terms of disciplinary values and norms stating that students' self-discipline awareness is highly emphasized so that expected values can be implemented according to the rules that have been applied in the school. SDIT Al-Madinah Pontianak (Ramdhani, Rustiyarso, $\&$ Supriadi, 2019). Then Nur Asiah and Ahmad Isnaeni that SDIT provides scientific excellence and noble character and makes a solution for busy parents have a reliable marketing strategy thus have competitiveness with other superior schools, both public 
and private (Asiah \& Isnaeni, 2018). SDIT pays excellent attention to detail in terms of classroom management, as the results of Novianti Muspiroh's research examines classroom management skills in science learning that are integrated with general science and religion (Novianti Muspiroh, 2019).

The results of the study strongly confirm that the interest of parents to register their children to SDIT is also due to the integration of the Islamic science curriculum and general science as a basic form of application of the two by internalizing religious values without distinguishing available science and spiritual knowledge (Saputra, Supriyanto, \& Timan, 2019); (Yani, Setyowat, Islamiyah, \& Pranggono, 2014); (Rohmad, Ikhwan, \& Tumin, 2020), as well as the opinion of Margustam, et al., who stated that at the philosophical level the integration of Islamic Religious Education (PAI) into the rational sciences was found in the formulation of the school's vision and mission to become a superior school in the aspect of Science. Knowledge and Technology (IPTEK) to support Faith and Taqwa (IMTAQ); at the material level, PAI material is integrated into social science, science, mathematics, and citizenship materials; while at the learning strategy level, the teacher integrates verses or hadiths along with their interpretations at each stage of the learning process which has an impact on increasing creative, innovative, critical thinking skills, and students' learning motivation. This integration also provides an understanding that Islam is a source of rational sciences and a source of values as described in the Qur'an and hadith that educates students to practice or contextualize the knowledge gained through attitudes and behaviour at school and in everyday life. (Siregar et al., 2020). Even SDIT also facilitates inclusive education (Barsihanor \& Anindia Rosyida, 2019).

For this reason, researchers are interested in knowing the secrets of the cause of the high enthusiasm of the community, especially parents, in registering their children in SDIT institutions, where no study of this enthusiasm has yet been discussed. The subject of the research was at the Integrated Islamic Elementary School (SDIT) Permata Hati Merangin Jambi to reveal data and information related to the concept and enthusiasm of the guardians of students enrolling their children at the Integrated Islamic Elementary School (SDIT) Permata Hati Merangin Jambi.

\section{METHOD}

Field research is included in qualitative research, which seeks to capture and translate the phenomena and facts related to SDIT Permata Hati Merangin Jambi by using descriptive-analytical research on the relationship with the community's enthusiasm factor for Integrated Islamic schools. The results of this study describe the findings obtained based on the results of interviews, Observations and documentation as they are (naturalistic) are then analyzed using inductive and deductive theories so that the object of research is well described.

\section{RESULT AND DISCUSSION}

\section{History of SDIT Permata Hati Merangin Jambi}

In the late 1980s, Integrated Islamic Schools began to emerge. This emergence was initiated by campus da'wah activists who are members of the Campus Da'wah Institute (LDK), Bandung Institute of Technology (ITB), University of Indonesia (UI), and 
several other well-known universities who are members of the Jama'ah Tarbiyah community who have concerns about the condition of education in Indonesia. Indonesia. They are campus Islamic activists who play an essential role in spreading Islamic ideology to students. Youth are the main target of this movement because they believe that youth will become agents of social change who are very important in Islamizing all Indonesian people (Qodir, 2009).

Along with that, in Merangin Regency in 2011, an Integrated Islamic School was also established under the auspices of the Permata Hati Foundation, by implementing it from the Kindergarten (TK), Elementary (SD) and High School (SMA) levels with the address in Salam Buku Village, Batang Masumai District, Jambi Province.

The Integrated Islamic Elementary School (SDIT) Permata Hati Merangin Jambi is designed as an excellent elementary school that pioneers the implementation of futureoriented integrated primary education to create a generation of Islamic characters that the people covet. This school became the first integrated Islamic education model to apply a full day school system (from 07.20 to 16.00). This school will be more flexible in developing its curriculum and various international education (Kepala SDIT Permata Hati Merangin Jambi, 2021).

The educators of SDIT Permata Hati Merangin Jambi are teachers who have been trained for a long time and have an Islamic personality to be role models for students, either as parents or friends for them at school. The educational qualifications of the teachers at SDIT Permata Hati Merangin Jambi from various universities are graduates of the Middle East Egyptian University, UIN Syarif Hidayatullah Jakarta, UIN Raden Intan Lampung, Islamic College (STAI) Bangko Jambi, and the College of Teacher Training and Education (STKIP). ) Bangko Jambi (SDIT Permata Hati Merangin Jambi, 2021). While the curriculum used by this school is a combination of the Education Office Curriculum, the Ministry of Religion Curriculum with the curriculum created by the Integrated Islamic School Network (JSIT), which is in the process of being implemented simultaneously (Erwanto, 2019).

The implementation of SDIT Permata Hati Merangin Jambi synergizes between teachers, parents and the community. This synergy is integration in educating students (Purwidiyanto, 2017). Education can rely on schools or parents, or the community, but these three components must run simultaneously.

\section{Factors of Community Enthusiasm for Integrated Islamic Schools}

The Integrated Islamic School is classified as a newcomer to the education model offered in Indonesia. However, as a newcomer, the integrated Islamic education system is very well received by the Indonesian people. This can be seen from several statistical data on new student admissions every new academic year, which always shows an increase in Integrated Islamic Schools (Aguswan Rasyid, 2021). Based on research in the field, it was found several factors that made people enthusiastic about entrusting their children to study in integrated Islamic schools, namely:

\section{Aspects of Integration of General Curriculum and Religion}

The dichotomy between religious science and non-religious science is not new. Islam has had this dichotomy tradition for more than a thousand years. But the paradox did not cause too many problems in the Islamic education system, so the Western secular education system was introduced to the Islamic world through imperialism. This happens because even though the dichotomy between religious sciences and non- 
religious sciences has been known in classical works such as those written by alGhazali and Ibn Khaldun, they do not deny but acknowledge the validity and scientific status of each of these scientific groups (Kartanegara, 2005).

In contrast to the dichotomy known by the Islamic world, modern Western science often underestimates the scientific status of the religious sciences. When discussing the occult sciences (faith), spiritual knowledge cannot be considered scientific because science can be regarded as scientific if the objects are empirical. Whereas the religious sciences certainly cannot avoid talking about unseen things (faith).

When these positivistic secular sciences were introduced to the Islamic world through Western imperialism, there was a very strict dichotomy between the religious sciences, as maintained and developed by traditional Islamic educational institutions (pesantren) on the one hand and secular sciences as taught in public schools sponsored by the government on the other hand.

This dichotomy becomes very sharp because there has been a denial of the validity and scientific status over the other. The traditionalists consider that the general sciences are heretical and forbidden to be studied because they come from unbelievers. In contrast, the proponents of the available sciences regard the general sciences as pseudo-scientific or just as myths that will not reach the scientific level because they do not speak about facts but about meanings that are not empirical (Rodiyah, 2014). At this time, this kind of dichotomy has caused various acute problems in the Islamic education system.

This can be proven by the existence of two models of formal education institutions in Indonesia. The first model is public schools such as elementary, junior high, and high school. The second model is schools known as religious schools such as Madrasah Ibtidaiyah (MI), Madrasah Tsanawiyah (MTs) and Madrasah Aliyah (MA). This second model, which in the national education system, is a manifestation of Islamic educational institutions. Religious schools have a curriculum composition of $30 \%$ religious subjects while the remaining $70 \%$ are general subjects (Fathoni, 2005); (Ikhwan, 2013); (Afiful Ikhwan, 2019).

This percentage proves that there is a substantial separation between religious subjects and general subjects. As a result, many issues are essentially studying God's verses but are entirely cut off from the greatness of God. For example, a science subject talking about nature, in other words, talks about the poems of God's kauniyah, but these lessons rarely introduce the greatness of God.

Soeroyo, as quoted by Muslih Usa, added that there are two kinds of God's verses, namely, first, qauliyah verses, which are verses written in the holy book. The second is the Kauniyah verse, namely the unwritten verses of God in the form of nature and everything around us. Between the two, it is impossible for there to be a difference, let alone a contradiction. Science as a formula for the stability of the universe is also impossible to contradict the Qur'an. If Islam originates from the Qur'an for the benefit of humankind and nature as well as for the people, then what is contained in the universe with its changes must be illuminated by the lamp of written revelation (Usa, 1991).

The statement above indicates that Islam does not recognize the existence of a dichotomy between general science and religious science because they are both verses of God. Syafi'i Ma'arif, quoted by Muslih Usa and Aden Wijaya, argues that Islamic 
education now adheres to the late medieval heritage education system. The main characteristic of the heritage is the clear separation between the classified knowledge (religious and general). At the same time, the position of Islamic education as a subsystem of national education is the other side that comes from the actual state administration system and an imperfect modification of the past historical heritage of modern education that we adhere to. As a result, this phenomenon has more or less affected education, especially Islamic education (Muslih Usa \& Aden Wijaya, 1987).

Conditions like this certainly cause Islamic education to suffer losses because what these school models produce are humans who are left behind by advances in science and technology on the one hand and on the other hand are also left behind in religious knowledge. Left behind in the field of science and technology because not all of the time and potential is used to study science and technology due to the curriculum that must be followed, left behind in the field of religion because the existing curriculum contains only a few religious lessons, and even then the material has been kept away from the values of monotheism. This causes the effort to change or form a Muslim personal figure as desired by Islamic education petite. Therefore, alternative Islamic educational institutions are needed that can eliminate the dichotomy of science.

As stated by many scientists in the Muslim world, the discourse of integration has developed in the past centuries. Nevertheless, the lesson until now officially still rarely becomes a characteristic of an educational institution.

According to Ainur Rofiq Dawam, the integration paradigm contains four sources of intellectual treasures that must be developed. The sources of intellectual treasures are a revelation (al-Qur'an and Hadith), verses of kauniyah (the universe), poems of ijtima'iyyah (social interaction), and verses of wujdaniyah (personal conscience) (Zamzami, 2015).

The four sources of treasure each have their area. For example, revelation has a clear and definite place, namely in the form of scriptural texts contained in the Qur'an and al-Hadith. The Islamic intellectual treasures from this first source gave rise to various disciplines, the most important of which was monotheism, the science of faith, and the science of law or sharia. Although these two disciplines have different formal objects, seen from the material object, they are the same, namely the texts in the Qur'an or Sunnah.

The second area of intellectual treasure, which is sourced from the verses of kauniyah (the universe), is different from the area of academic glory that comes from revelation. This intellectual treasure area gives greater attention to natural phenomena, giving rise to various scientific disciplines, notably philosophy, science, and technology. However, it is unfortunate that this second treasure area is still underdeveloped in the Islamic world (Ikhwan, Ju'subaidi, Mu'awanah, \& Rohmad, 2019).

The area of treasury originating from the verses of ijtima'iyyah (social interaction) is very different from the two previous intellectual treasures. This treasure area looks more deeply at the models and processes of interaction among human beings. This intellectual treasure area gave rise to several disciplines, especially politics and economics. The second and third treasure areas almost have similarities but are substantially different.

Fourth, the area of intellectual treasure sourced from the verses of wujdaniyah (personal experience or conscience) emphasises the understanding and conscience of a 
person who is not the same and is not easily imitated by others. This is what in its development gave rise to the science of Sufism which is often controversial, both in the perspective of the first, second, or third Islamic intellectual treasures. The researchers describe this in the following diagram:

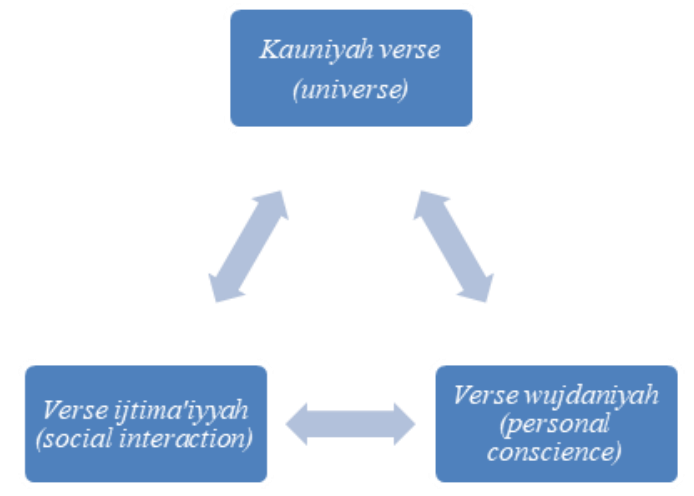

Figure 1. Essential Aspects of the Source of Integration of General and Religious Sciences

Integrated Islamic Schools are newcomers to the education scene in Indonesia, so they have a flexible choice of curriculum applied. However, there are specific considerations that are used when choosing the curriculum to be applied. These considerations, for example, are pragmatic. Because they are in the Unitary State of the Republic of Indonesia (NKRI) territory, they must choose between the Ministry of Education and Culture curriculum and the Ministry of Religion. This consideration is carried out to provide added value to the users of these educational institutions.

"Administratively, we are under the Ministry of Education and Culture because we use the names SD, SMP, and SMU. Why choose to use the names SD, SMP, and SMU? This is more of a pragmatic consideration. Because in the community's eyes, the names SD, SMP, and SMU are more of choice compared to other names, for example, madrasas. Because we use that name, like it or not, we also have to use the curriculum model, although we always make modifications to the characteristics of our school." (Kepala SDIT Permata Hati Merangin Jambi, 2021).

Thus, the curriculum applied by the Integrated Islamic School is a curriculum adapted from the curriculum of the Ministry of Education and Culture with various modifications here and there. The Integrated Islamic School is an integral part of the national education system if you look at the curriculum structure. The Integrated Islamic School accepts all subjects from the national curriculum. The National Education Standards Agency compiled the curriculum (BSNP), later used as Minister of Education and Culture Regulation No. 22 of 2006. There are eight subjects for elementary school students plus local content and self-development, ten subjects for junior high school or Madrasah Tsanawiyah plus local content and self-development, 15 subjects for high school or Madrasah Aliyah plus content local and selfdevelopment (Pemerintah Republik Indonesia, 2009); (Ikhwan, 2020).

The Integrated Islamic School accepts the subjects of Mathematics, Natural Sciences, Social Sciences, Languages and Arts, which are the standard formats of the national education curriculum. The Integrated Islamic School considers that providing general subjects can be a tool to equip graduates to develop their students' future professions as engineers, economists, doctors, psychologists, and other works. The modern education system approach is taken to support the implementation of the curriculum 
and distinguish it from the pesantren system. The curriculum offered by pesantren by focusing on traditional religious sciences ultimately becomes the target of criticism because the curriculum produces graduates who will not be able to face the challenges of the times (Hasan, 2009).

Thus the Permata Hati Merangin Jambi Integrated Islamic School not only has an idea or wishful thinking about the integration of knowledge, but the management of the Integrated Islamic School from the lowest level to the top level has a high commitment to realizing the concept of integrated Islamic education by always paying attention to the needs and developments in society.

\section{Full day school system}

Another exciting thing about the Integrated Islamic School is implementing the fullday school system, which requires students to follow the learning process longer, starting at 07.00-15.00 WIB. This longer learning time allows the Integrated Islamic School to teach all the materials contained in the curriculum, including other religious curricula, Arabic and the Qur'an (Ikhwan, Anwar, \& Mahmudah, 2021). Moreover, students also can practice what they have learned, especially those related to the religious curriculum. Schools can further instil religious, moral values through the congregational prayer program and kultum (lectures), which will become the principal capital for shaping students' spiritual integrity. At the same time, students can also interact intensively with teachers who act as observers of their behaviour and, at the same time, as mentors, guiding students directly on how to be a good Muslim. Moreover, the full-day school system is believed to be able to develop their creativity and talents optimally. With this system, students can choose various activities according to their abilities.

There are several arguments that the rise of the full day school program is influenced by many factors, including social, economic, and educational aspects. In addition, the increasing number of single-parent families or families where husband and wife work together tends to hold full day school programs (Fatchurrohman, 2007). Economically, child care during working hours is considered cheaper and more straightforward when compared to part-day schooling. Usually, the part-day school for a pre-kindergarten level prepare children cognitively, socially and physically before kindergarten education. Several supporters of full day kindergarten said that some parents were attracted by the benefits of this program, especially to prepare better children to receive the entire curriculum ultimately.

Regarding the full day school system implemented by the Integrated Islamic School, such as at the research location of SDIT Permata Hati Merangin Jambi, there are fundamental considerations from some parents who encourage them to choose SDIT as a place of education for their children. The awareness of the importance of Islamic education is a significant factor, in addition to other technical aspects such as wanting to leave their children because they are busy working until the afternoon so that children do not continue to play or watch TV and play cellphone games so that they neglect their studies (Srinadi Eka Arista; Nilakusmawati, Desak Putu Eka, 2020). In general, it can be said that the parents or guardians of students who send their children to this institution are because they technically feel they cannot control their children at home for several reasons. Actually, with the full day school system, the teacher's task becomes more complex and extra in educating and supervising the development of 
students because some of the guardians of students already believe in entrusting their children to school at the SDIT.

"The full day school system is a reneged unit between various components in the school and especially the guardians of students as controllers and creators of the learning atmosphere at home." (Arsyida, 2021).

The full day school system is beneficial for the urban middle class and busy working parents. By sending their children to schools with this system, they do not need money to care for their children. They don't even have to worry about their children's activities after school because they are full at school until the afternoon when the parents have come home from work and are back home. This is considered an alternative solution when parents are worried about moral decay among the younger generation. They only need to pay a bit extra money for extra-curricular activities, which are no more than Rp. 600,000. This amount is slightly more expensive when compared to other schools as a consequence of the full day school system (Hasan, 2009).

Schools need additional facilities, including having to provide lunch and child monitoring fees for a full day. Most upper-middle class, especially those whose guardians are State Civil Apparatus (ASN), prefer to send their children to Integrated Islamic Schools. This is also in line with working hours in Indonesia (from 07.0013.30 for six working days and 08.00-04.00 for five working days), leaving them not having time to take care of their children if they send them to public schools that are not implementing a full day school system. The researchers' interest in full day school is illustrated in the following diagram:

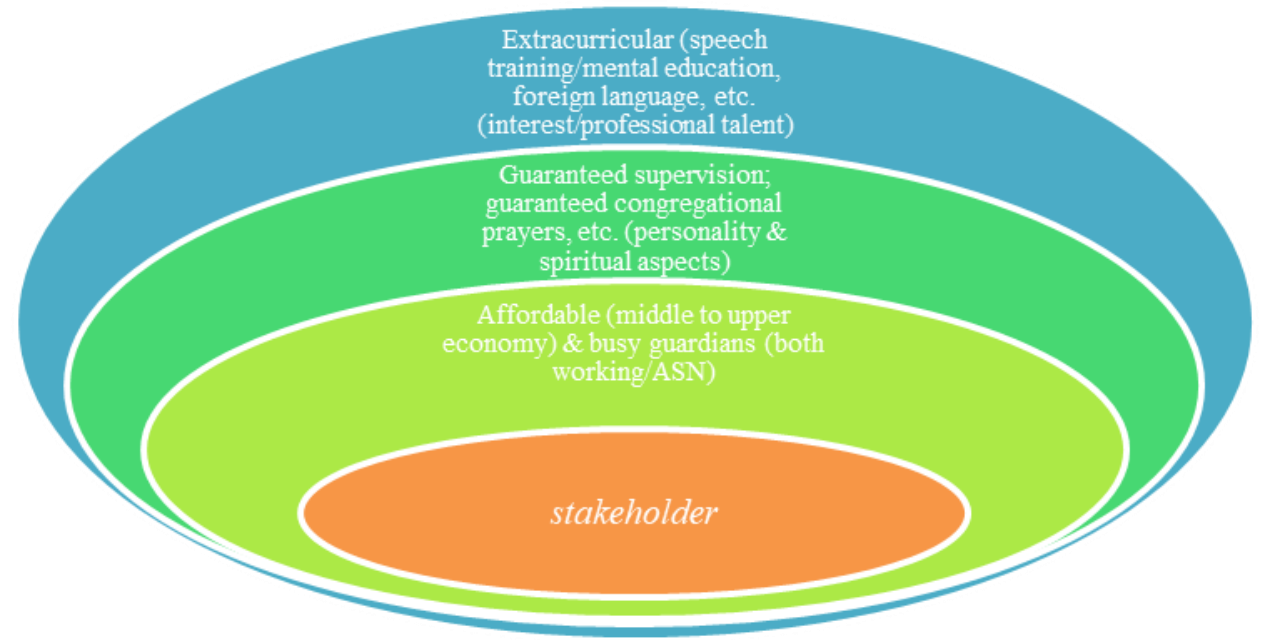

Figure 2. The Attractiveness of the Trend of Community Enthusiasm towards Fullday Schools

The full day school system is considered a practical solution for them. These are some of the advantages that motivate parents from the upper-middle class to send their children to Integrated Islamic Schools, which ultimately contribute to the success of several Integrated Islamic Schools in increasing their status as established, if not elitist, schools. This is similar to the Permata Hati Merangin Integrated Islamic Elementary School, Jambi, where the average student is upper-middle class. A community has realized the importance of Islamic education and the cultivation of religious, moral values as a provision for children to face future challenges (Kepala SDIT Permata Hati Merangin Jambi, 2021). 


\section{Parental Involvement and in School Activities}

Education is a conscious process to transfer knowledge to children to shape and develop their potential. A good education is not solely charged to teachers or educators in schools to realise these educational goals. Still, also parents have a big responsibility and role in achieving goals, meaning that synergy between teachers in schools and parents is essential in the learning process.

The family is the first educational environment recognized by children, and parents are the first coaches (Hawari, 1998). Parents' personalities, attitudes, and way of life are elements of indirect education that will automatically enter into the nature of the growing child. The development of children's mentally and intellectually mental (IQ) and mental emotional (SQ) is strongly influenced by parents' attitudes, ways, and personalities in educating their children.

The Integrated Islamic Elementary School (SDIT) Permata Hati Merangin Jambi realizes that building students' character cannot be separated from three elements that influence the education process, family and society. So it has strived that the three elements are in synergy in parenting.

The involvement of parents in schools is sought so that there is effective communication and a harmonious relationship between the school and parents in the form of:

a. Pengajian (liqo'): This joint recitation or Liqo' aims to speed up the forum for friendship between teachers, students, parents and the foundation and introduce them to long-term life in the hereafter. Besides, this activity also instilled the spirit of leadership to become a pious child. This activity usually takes lecturers from the school teacher itself and some outside the school. This recitation is held once a week, where the implementation is at the school and the head of the foundation (Kepala SDIT Permata Hati Merangin Jambi, 2021).

b. Commemoration of Islamic Holidays (PHBI): The purpose of holding memorials and celebrations of Islamic holidays is to train students to consistently participate in efforts to spread Islam in people's lives through positive and good value activities for internal development within the community. Wider community environment. This activity is directed at self-development, fostering a love for Islam. This activity can also be formed through social activities both in the school environment and outside, especially charity for orphans and the poor. The commemoration of this Islamic holiday includes the anniversary of the birth of the Prophet Muhammad, isra 'mi'raj, nuzulul qur'an, zakat fitrah and 'idul qurban.

c. Social Worship: Social worship carried out at the Integrated Islamic School begins with infaq collected by teachers, students, parents and congregation, with the aim that students and communities of the regular recitation have a high social spirit and concern to the environment. The implementation of this activity is included at every moment, such as the commemoration of Islamic holidays. The infaq that has been collected will be donated to the poor, orphans and the poor (miserable). 


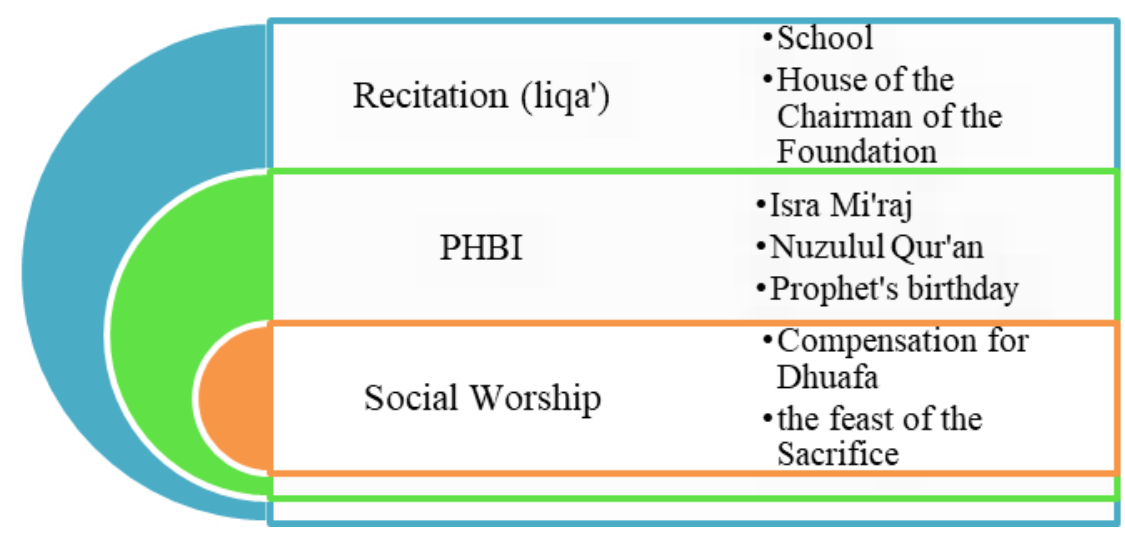

Figure 3. The Role of Synergy in SDIT Schools

So Permata Hati Merangin Jambi Integrated Islamic Elementary School is well aware that educating children and educational institutions can be done by one component of the teacher, but the parent component is also essential.

\section{CONCLUSION}

From the explanation of the above discussion, it can be concluded that the problems of the enthusiasm of the community (parents) to enroll their children in the Integrated Islamic School are (1) the integration of the Islamic education curriculum and general education; it is actually implemented and not just a mere slogan; (2) Integrated Islamic Schools implement a full day school learning system, because this model system has many benefits, especially respect for time and maintaining congregational prayers, also by maximizing extracurricular activities such as: deepening Arabic, speech exercises (mental education) and most importantly The critical thing is that the majority of both parents are busy working and feel more comfortable sending their children to school with a full day school system; and (3) Parents are personally also actively involved in guiding children to learn, in the form of: recitation (liqa') which must be attended by students and their guardians which are scheduled every week at school and at the house of the Foundation Chairperson, then accompanied by a compensation agenda. Or infaq to the poor orphans; commemorate Islamic holidays together such as the prophet's birthday, isra 'mi'raj, nuzulul qur'an. With the results of this study, it is hoped that the world of education, especially integrated Islamic schools, can continue to improve the quality of education. So that people don't have to work hard to find the best place for education for their children.

\section{REFERENCES}

[1] Afiful Ikhwan. (2019). Konsep Dasar Pengembangan Kurikulum Pendidikan Agama Islam. (Ferry Irawan Febriansyah, Ed.). Ponorogo: Umpo Press.

[2] Aguswan Rasyid, E. M. (2021). Sejarah Islam Pada Masa Pandemi Di SDIT AlMarhamah Kampung. Inovasi Pendidikan, (Vol 8, No 1a (2021): Volume 8 No. 1a, Juli 2021).

[3] Arsyida. (2021). Wawancara guru SDIT Permata Hati Merangin Jambi. Jambi.

[4] Aryati, A. (2016). Pemikiran Pendidikan Al-Mawardi (Etika Antara Guru - Murid). At-Ta'lim : Media Informasi Pendidikan Islam, (Vol 15, No 1 (2016): JUNI), 207- 
224.

[5] Asiah, N., \& Isnaeni, A. (2018). Inklinasi Masyarakat Muslim Kelas Menengah Terhadap Sekolah Dasar Islam Terpadu di Bandar Lampung. Al-Tadzkiyyah: Jurnal Pendidikan Islam, 9(2), 291. https://doi.org/10.24042/atjpi.v9i2.3452

[6] Barsihanor, B., \& Anindia Rosyida, D. (2019). Implementasi Pendidikan Inklusi Pada Sekolah Dasar Islam Terpadu Al-Firdaus Banjarmasin. Jurnal Tarbiyatuna, 10(2), 147-166. https://doi.org/10.31603/tarbiyatuna.v10i2.2712

[7] Erwanto, E. (2019). Penerapan Kurikulum Jaringan Sekolah Islam Terpadu (Jsit) Dalam Pembentukan Karakter Religius Siswa Smpit Khoiru Ummah Rejang Lebong. Al-Bahtsu: Jurnal Penelitian Pendidikan Islam, (Vol 4, No 1 (2019): Juni).

[8] Fatchurrohman, F. (2007). Fenomena Madrasah Bubar dan Islamic Fullday School. EDUKASI: Jurnal Penelitian Pendidikan Agama Dan Keagamaan, (EDUKASI | VOLUME 5, NOMOR 3, SEPTEMBER 2007).

[9] Fathoni, M. K. (2005). Pendidikan Islam dan Pendidikan Nasional. Jakarta: Departemen Agama RI.

[10] Hasan, N. (2009). Islamizing formal education: integrated Islamic school and a new trend in formal education institution in Indonesia (No. 172). RSIS Working Paper. Singapore.

[11] Hawari, D. (1998). AlQur'an dan Ilmu kedokteran Jiwa dan Kesehatan Jiwa. Yogyakarta: Dana Bakti Primayasa.

[12] Ikhwan, A. (2013). Optimalisasi Peran Masjid Dalam Pendidikan Anak: Perspektif Makro Dan Mikro. Edukasi: Jurnal Pendidikan Islam, 1(1), 1-16.

[13] Ikhwan, A. (2017). Metode Simulasi Pembelajaran dalam Perspektif Islam. ISTAWA: Jurnal Pendidikan Islam, 2(2), 1-34.

[14] Ikhwan, A. (2018). Filsafat Pendidikan Islam: Memahami Prinsip Dasar. Yogyakarta: Diandra Kreatif.

[15] Ikhwan, A. (2020). Development of Educational Resources in Junior High Schools to Obtain Quality. Cendekia: Jurnal Kependidikan Dan Kemasyarakatan, 18(1), 116. https://doi.org/10.21154/cendekia.v1i1.1897

[16] Ikhwan, A., Anwar, S., \& Mahmudah, N. (2021). Tahsin and Tahfidz Learning System at Integrated Islamic Elementary School (SDIT) Insan Madani During the Pandemic Covid-19. Al-Hayat: Journal of Islamic Education (AJIE), 5(1), 1-11.

[17] Ikhwan, A., Biantoro, O. F., \& Rohmad, A. (2019). The Role of the Family in Internalizing Islamic Values. Dinamika Ilmu. https://doi.org/10.21093/di.v19i2.1746

[18] Ikhwan, A., Ju'subaidi, J., Mu'awanah, E., \& Rohmad, A. (2019). Development of Curriculum Keaswajaan (Nahdlatul 'Ulama) in Character Formation. https://doi.org/10.4018/978-1-5225-8528-2.ch006

[19] Imron, A. (2011). Supervisi Pembelajaeran Tingkat Satuan Pendidikan. Jakarta: Bumi Aksara.

[20] Kartanegara, M. (2005). Integrasi Ilmu. Jakarta: Mizan. 
[21] Kepala SDIT Permata Hati Merangin Jambi. (2021). Wawancara. Jambi.

[22] Muslih Usa, \& Aden Wijaya. (1987). Pendidikan Islam dalam Peradaban Industrial. Yogyakarta: Aditia Media.

[23] Mutohar, P. M. (2006). Hubungan Gaya Kepemimpinan Kepala Sekolah, Budaya Organisasi, Iklim Organisasi, Semangat Kerja, dan Motivasi Berprestasi Guru Dengan Kinerja Guru SMPN Di Kabupaten Tulungagung. Universitas Negeri Malang.

[24] Novianti Muspiroh. (2019). Manajemen Kelas Pembelajaran Sains Di Sekolah Dasar Islam Terpadu Sabilul Huda Kota Cirebon. JIEM (Journal Islamic Education of Management), 3(2), 146-158.

[25] Pemerintah Republik Indonesia. (2009). Peraturan Menteri Nomor 22 Tahun 2006 Tentang Standar Isi Untuk Satuan Pendidikan Dasar Dan Menengah, 1-35.

[26] Purwidiyanto. (2017). Pendidikan Lingkungan Hidup Dalam Perspektif Islam. Jurnal Pendidikan Islam, (Vol. 8 No. 2 (2017)), 205-228.

[27] Qodir, Z. (2009). Gerakan Sosial Islam: Manifesto Kaum Beriman. Yogyakarta: Pustaka Pelajar.

[28] Ramdhani, Y., Rustiyarso, \& Supriadi. (2019). Penerapan Nilai Dan Norma Kedisiplinan Sekolah Dasar Islam Terpadu Al-Madinah Pontianak. In Proceedings International Conference on Teaching and Education (ICoTE) (Vol. 2, pp. 277279).

[29] Rodiyah, R. (2014). Paradigma Integrasi Interkoneksi Ilmu Agama Dan Ilmu Umum (Fungsi Manajemen Dalam Al-Qur'an). BINA AL UMMAH, (Vol 9, No 1 (2014): Bina al-ummah), 101-110.

[30] Rohmad, A., Ikhwan, A., \& Tumin, T. (2020). Strengthening the competency of lecturers of state Islamic religious college in Indonesia. International Journal of Advanced Science and Technology, 29(4), 1653-1663.

[31]Sabda, S. (2006). Model kurikulum Terpadu Iptek dan Imtaq, Desain, Pengembanagan dan Implementasi. Jakarta: Quantum Teaching.

[32] Saputra, B. R., Supriyanto, A., \& Timan, A. (2019). Internalisasi Nilai-Nilai Religius dalam Penjaminan Mutu Sekolah Dasar Islam Terpadu. Ilmu Pendidikan: Jurnal Kajian Teori Dan Praktik Kependidikan, 4(1), 13-18.

[33] SDIT Permata Hati Merangin Jambi. (2021). Buku Pedoman Pendidikan SDIT. Jambi: SDIT Permata Hati Merangin Jambi.

[34] Simatupang, N., \& Abduh, R. (2020). Pendidikan Anti Kekerasan Bagi Masyarakat Guna Pencegahan Perilaku Kekerasan Terhadap Anak. DE LEGA LATA: Jurnal Ilmu Hukum, 5(1), 1-9. https://doi.org/10.30596/dll.v5i1.3290

[35] Siregar, M., Zahra, D. N., \& Bujuri, D. A. (2020). Integrasi Materi Pendidikan Agama Islam Dalam Ilmu-Ilmu Rasional Di Sekolah Menengah Atas Islam Terpadu. Al-Tadzkiyyah: Jurnal Pendidikan Islam, 10(2), 183-201. https://doi.org/10.24042/atjpi.v10i2.4847

[36] Srinadi Eka Arista; Nilakusmawati, Desak Putu Eka, I. G. A. Y. U. M. A. (2020). Hubungan Kecanduan Bermain Game Online Terhadap Interaksi Sosial Pada Remaja. E-Jurnal Matematika, (Vol 9 No 3 (2020)), 177-181. 
[37] Suhardan, D. H. (2010). Supervisi Profesional: Layanan dalam Meningkatkan Mutu Pembelajaran di Era Otonomi Daerah. Bandung: Alfabeta.

[38] Supriyono. (2018). Model Supervisi Pembelajaran Tim Partisipatif Berbasis Pondok Pesantren. LPPM UNISBA Blitar.

[39] Suyatno. (2015). Sekolah Dasar Islam Terpadu Dalam Konsepsi Kelas Menengah Muslim Indonesia. Analisa Journal of Social Science and Religion, 22(1), 121-133.

[40] Usa, M. (1991). Pendidikan di Indonesia antara Cita dan Fakta. Yogyakarta: PT. Tiara Wacana.

[41] Yani, M. T., Setyowat, R. N., Islamiyah, D. N., \& Pranggono, G. (2014). Konstruksi Kurikulum dan Pembelajaran Terpadu antara Pendidikan Agama Islam (PAI) dan Pendidikan Kewarganegaraan (PKn) di Sekolah Dasar. ISLAMICA: Jurnal Studi Keislaman, 6(1), 168. https://doi.org/10.15642/islamica.2011.6.1.168179

[42] Zamzami, M. S. (2015). Tafsir Ideologis dalam Khazanah Intelektual Islam. MUTAWATIR, 4(1), 163. https://doi.org/10.15642/mutawatir.2014.4.1.163-177

[43]Zepeda, S. J. (2007). Instructional Supervision: Applying Tools and Concepts. Larchmont: NY: Eye on Education. 